\title{
Quality of Life Questionnaires in Breast Cancer-Related Lymphedema Patients: Review of the Literature
}

\author{
Anouk J.M. Cornelissen, MD, ${ }^{1, *}$ Melissa Kool, MD, ${ }^{2, *}$ Xavier H.A. Keuter, MD, PhD, \\ Esther M. Heuts, MD, PhD, Andrzej A. Piatkowski de Grzymala, MD, PhD, \\ René R.W.J. van der Hulst, MD, PhD, and Shan Shan Qiu, MD, PhD ${ }^{1}$
}

\begin{abstract}
Purpose: Lymphedema of the arm is one of the most common and underestimated side effects of breast cancer treatment. It is known to negatively affect the quality of life $(\mathrm{QoL})$ in breast cancer survivors. However, there are multiple questionnaires used to measure $\mathrm{QoL}$ in lymphedema patients. The current study aimed to determine the most complete and accurate questionnaire.

Methods: A systematic literature search in Cochrane Library database CENTRAL, MEDLINE, and EMBASE was conducted in August 2016 by two independent researchers. The strategy used for the search was: (("Lymphedema" [Mesh]) AND ("Quality of life"[Mesh])). All QoL questionnaires for patients with breast cancer-related lymphedema (BCRL) were included. An overview of the assessed QoL domains and arm symptom-specific questions was made, to assess the most complete and accurate questionnaire.

Results: A total of 142 studies were identified, of which 49 met the inclusion criteria and 15 different questionnaires were extracted. The Lymphedema Quality of Life Inventory (LyQLI), assesses all QoL domains, except for the possibility of wearing the clothes of choice, and assess all specific arm symptoms. The Lymphedema Functioning, Disability, and Health (Lymph-ICF) Questionnaire assesses all QoL domains, except for sexual functioning, and does assess all specific arm symptoms.

Conclusion: According to the results obtained, the LyQLI and Lymph-ICF questionnaires were the two most complete and accurate questionnaires to assess QoL in patients with BCRL, because these questionnaires assess the largest number of QoL domains and specific arm symptoms.
\end{abstract}

Keywords: breast cancer, lymphedema, quality of life, questionnaire

Introduction

B REAST CANCER IS THE most frequent cancer affecting women all over the world and its incidence has doubled during the last decades. ${ }^{1,2}$ Due to early detection and improved treatment there is an increased number of long-term breast cancer survivors. $^{1-3}$ Therefore, there is an increased focus on the quality of life (QoL) and Patient Reported Outcome Measures (PROMs). ${ }^{4,5}$ Besides, the overall QoL in these longterm breast cancer survivors is important to measure the impact of specific treatments on the different QoL domains. ${ }^{6-8}$

Lymphedema of the arm is considered one of the most distressing and underestimated side effects of breast cancer treatment. ${ }^{9-13}$ Breast cancer-related lymphedema (BCRL) is caused by an acquired interruption of the axillary lymphatic system after locoregional treatment such as radiotherapy and/or lymph node dissection. ${ }^{14-17}$ Previous studies showed that the incidence of lymphedema of the arm ranged between $8.4 \%$ and $21.4 \%$ after breast cancer treatment, with an estimate incidence of $16.6 \%{ }^{18}$

Lymphedema is known to have a significant impact on the physical, psychological, and social health of patients. ${ }^{18-21}$ To measure the actual impact of BCRL on QoL, a good questionnaire is mandatory. However, there is no consensus about the best questionnaire to measure $\mathrm{QoL}$ in these patients with BCRL. Several different questionnaires have been used for patients with BCRL in previous studies. ${ }^{22-35} \mathrm{~A}$ recent review assessed the quality of four QoL questionnaires in patients with BCRL. ${ }^{36}$ However, more different questionnaires than four

\footnotetext{
${ }^{1}$ Department of Plastic and Reconstructive Surgery, Maastricht University Medical Center, Maastricht, The Netherlands.

${ }^{2}$ Department of Surgery, Maastricht University Medical Center, Maastricht, The Netherlands.

*These authors contributed equally to this work.
} 
have been used in all other previous studies. ${ }^{22-35}$ Furthermore, the previous review compares the validity of the questionnaires, but the amount of different aspects of QoL was not taken in account. In the present study a literature review was performed to provide an overview of the different questionnaires, to assess the most complete and accurate one, not only based on validity but also on the amount of different aspects of QoL. The different subdomains included in the questionnaires were analyzed to target the impact of BCRL with more accuracy.

\section{Methods}

This systematic review was conducted according to the PRISMA guidelines. ${ }^{37}$

\section{Data sources}

A systematic literature search in MEDLINE, EMBASE, and the Cochrane Library database CENTRAL was conducted in March 2017 to identify all questionnaires reporting on QoL in BCRL patients. The search was performed using predefined search terms: (("Breast cancer-related lymphedema"'[Mesh]) AND ("Quality of life"'[Mesh])). The reference lists of included articles were hand searched to supplement the literature search to ensure that no relevant studies were missed by the search strategy.

\section{Selection process}

Eligibility assessment of the articles was performed in a standardized manner by two independent reviewers. The title and abstract of all retrieved hits were screened and reviewed individually to identify all relevant articles reporting on QoL in patients with lymphedema of the arm. No restrictions for language, publication date, or publication type were applied. All variations of questionnaires measuring QoL were identified based on the full-text versions of the articles. Disagreements between both reviewers were resolved by consensus.

\section{Data extraction}

A data extraction sheet was developed containing information about the questionnaires. For each of these questionnaires, the following variables were gathered: full name and abbreviation of the questionnaire, validity (Cronbach's alpha coefficient), type of answer, and the assessed QoL domains (physical function, mental function, daily activities, hobbies and job, mobility, social activities, and sexual function). Using this data extraction sheet, a selection of questionnaires was made, based on the number of QoL domains assessed. Questionnaires which assessed all or all except one QoL domains were selected. For the selected questionnaires another data extraction sheet was developed, containing information about the arm symptom-specific questions, which were assessed in the questionnaires. Specific arm symptoms were: pain, heaviness, swelling/tightness, loss of strength, tingles/burning/pins, skin problems, possibility to elevate the arm, movement difficulties of the arm, and problems in wearing the clothes of choice.

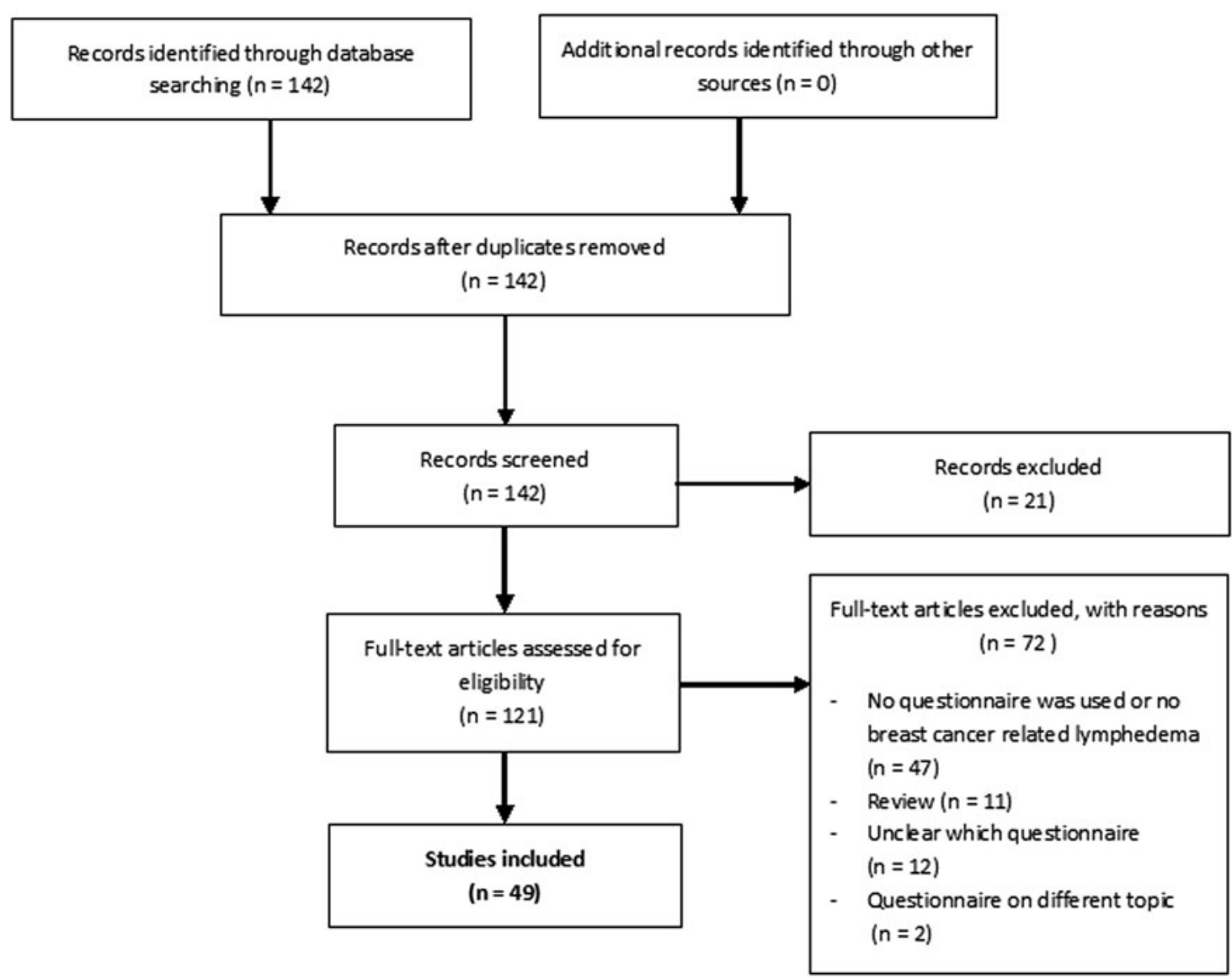

FIG. 1. Flow diagram of the literature search according to PRISMA statement. 


\section{Results}

\section{Study selection}

The literature search identified a total number of 142 studies. After selection, using the criteria described in Figure 1, 49 studies were included. In these 49 studies, 15 different questionnaires were used.

\section{Questionnaire characteristics}

The 15 identified questionnaires were subdivided in three categories:

Group I: General health questionnaires; this group consisted of six questionnaires.

Group II: Cancer-specific questionnaires; this group consisted of three questionnaires.

Group III: Lymphedema-specific questionnaires; this group consisted of six questionnaires.

All of the assessed questionnaires were validated previously (Table 1).

In group I, one out of six questionnaires used a combination of visual analogue scale (VAS) score and categories. The rest of the questionnaires used categories. All the questionnaires reported on mental function. Only one questionnaire reported on hobbies and jobs. Four questionnaires reported on physical function and daily activities. In addition, only one questionnaire included questions on mobility, two on social activity, and one on sexual function. The DASH questionnaire was the only questionnaire in this group which assessed all QoL domains.

In group II, the EORTC QLQ-C30 is a cancer-specific questionnaire, which is commonly used in combination with the EORTC QLQ-BR23 questionnaire. Altogether, these questionnaires provide a complete breast cancer-specific questionnaire, assessing all QoL domains. All questionnaires in this group used a categorical score.

In group III, only the Lymphedema Functioning, Disability and Health (Lymph-ICF) questionnaire used a VAS score. The rest of the questionnaires used categories. Two out of six questionnaires assessed all QoL domains, the other four assessed all QoL domains, except for sexual function (Table 2).

Eight of the included questionnaires assessed all or all except one QoL domains; these questionnaires were selected for further analyses on assessment of arm symptom-specific questionnaires. Four of them assessed all QoL domains, the

Table 1. Overview of Assessed Questionnaires, with Validation

\begin{tabular}{|c|c|c|c|c|c|}
\hline $\begin{array}{l}\text { Questionnaire } \\
\text { (abbreviation) }\end{array}$ & $\begin{array}{l}\text { Questionnaire } \\
\text { (full name) }\end{array}$ & $\begin{array}{l}\text { No. } \\
\text { of studies }\end{array}$ & $\begin{array}{l}\text { Validation } \\
\text { Author } \\
\text { Year }\end{array}$ & $\begin{array}{l}\text { Consistency } \\
\text { validity }(\mathrm{n})\end{array}$ & $\begin{array}{l}\text { Cronbach's } \\
\alpha \text { coefficients }\end{array}$ \\
\hline \multicolumn{6}{|l|}{ Group I } \\
\hline SF-36 & Short Form 36 & 12 & $\begin{array}{l}\text { Brazier et al. } \\
\quad 1992\end{array}$ & 1582 & $0.73-0.96$ \\
\hline DASH & $\begin{array}{l}\text { Disabilities of Arm, } \\
\text { Shoulder, and Hand }\end{array}$ & 4 & $\begin{array}{l}\text { Dias et al. } \\
2008\end{array}$ & 100 & 0.98 \\
\hline HADS & $\begin{array}{l}\text { Hospital Anxiety } \\
\text { and Depression Scale }\end{array}$ & 1 & $\begin{array}{l}\text { Bjelland et al. } \\
2002\end{array}$ & Review & $0.67-0.93$ \\
\hline McGill Pain score & McGill Pain score & 1 & $\begin{array}{l}\text { Melzack } \\
1987\end{array}$ & 16 & $0.74-1.00$ \\
\hline MYMOP & $\begin{array}{l}\text { Measure Yourself } \\
\text { Medical Outcome Profile }\end{array}$ & 1 & $\begin{array}{l}\text { Barbosa Lima et al. } \\
2016\end{array}$ & 74 & $0.38-0.62$ \\
\hline PANAS & $\begin{array}{l}\text { Positive and Negative } \\
\text { Affect Schedule }\end{array}$ & 1 & $\begin{array}{l}\text { Watson et al. } \\
1988\end{array}$ & Unknown & $0.86-0.90$ \\
\hline \multicolumn{6}{|l|}{ Group II } \\
\hline EORTC QLQ-C30 & $\begin{array}{l}\text { Quality of Life } \\
\text { Questionnaire Core-30 }\end{array}$ & 12 & $\begin{array}{l}\text { Tan et al. } \\
2014\end{array}$ & 170 & 0.85 \\
\hline EORTC QLQ-BR23 & $\begin{array}{l}\text { Quality of Life } \\
\text { Questionnaire Breast-23 }\end{array}$ & 11 & $\begin{array}{l}\text { Sprangers et al. } \\
1996\end{array}$ & 170 & $0.57-0.89$ \\
\hline FACT-B & $\begin{array}{l}\text { Functional Assessment } \\
\text { of Cancer Therapy } \\
\text { Breast Cancer }\end{array}$ & 11 & $\begin{array}{l}\text { Coster et al. } \\
2001\end{array}$ & 279 & $0.62-0.88$ \\
\hline \multicolumn{6}{|l|}{ Group III } \\
\hline Lymph-ICF & $\begin{array}{l}\text { Lymphedema Functioning, } \\
\text { Disability, and Health }\end{array}$ & 5 & $\begin{array}{l}\text { Devoogdt et al. } \\
2011\end{array}$ & 60 & $>0.70$ \\
\hline ULL 27 & Upper Limb Lymphedema 27 & 3 & $\begin{array}{l}\text { Launois et al. } \\
2002\end{array}$ & 301 & $0.82-0.93$ \\
\hline LSIDS-A & $\begin{array}{l}\text { Lymphedema Symptom } \\
\text { and Intensity Survey-Arm }\end{array}$ & 1 & $\begin{array}{l}\text { Ridner et al. } \\
2015\end{array}$ & 236 & $0.93-0.94$ \\
\hline LyQLI & $\begin{array}{l}\text { Lymphedema Quality } \\
\text { of Life Inventory }\end{array}$ & 2 & $\begin{array}{l}\text { Klernäs et al. } \\
2015\end{array}$ & 126 & $0.87-0.92$ \\
\hline PBI-L & $\begin{array}{l}\text { Patient Benefit Index- } \\
\text { Lymphedema }\end{array}$ & 1 & $\begin{array}{l}\text { Blome et al. } \\
2014\end{array}$ & 65 & $0.80-1.00$ \\
\hline LYMQOL & $\begin{array}{l}\text { Quality of Life measure } \\
\text { for limb lymphedema }\end{array}$ & 1 & $\begin{array}{l}\text { Keeley et al. } \\
2010\end{array}$ & 209 & $0.83-0.88$ \\
\hline
\end{tabular}


Table 2. Overview of Assessed Quality Of Life Domains in the Different Questionnaires

\begin{tabular}{|c|c|c|c|c|c|c|c|c|}
\hline Questionnaire & Answer type & $\begin{array}{l}\text { Physical } \\
\text { function }\end{array}$ & $\begin{array}{c}\text { Mental } \\
\text { function }\end{array}$ & $\begin{array}{c}\text { Daily } \\
\text { activities }\end{array}$ & $\begin{array}{l}\text { Hobbies } \\
\text { and job }\end{array}$ & Mobility & $\begin{array}{c}\text { Social } \\
\text { activities }\end{array}$ & $\begin{array}{c}\text { Sexual } \\
\text { function }\end{array}$ \\
\hline \multicolumn{9}{|l|}{ Group I } \\
\hline SF-36 & Categories & $\mathrm{x}$ & $\mathrm{x}$ & $\mathrm{x}$ & - & - & $\mathrm{X}$ & - \\
\hline DASH & Categories & $\mathrm{x}$ & $\mathrm{x}$ & $\mathrm{x}$ & $\mathrm{X}$ & $\mathrm{X}$ & $\mathrm{x}$ & $\mathrm{X}$ \\
\hline HADS & Categories & - & $\mathrm{x}$ & - & - & - & - & - \\
\hline McGill Pain Score & Categories-VAS & $\mathrm{x}$ & $\mathrm{x}$ & $\mathrm{x}$ & - & - & - & - \\
\hline MYMOP & Categories & $\mathrm{x}$ & $\mathrm{x}$ & $\mathrm{X}$ & - & - & - & - \\
\hline PANAS & Categories & - & $\mathrm{x}$ & - & - & - & - & - \\
\hline \multicolumn{9}{|l|}{ Group II } \\
\hline EORTC QLQ-C30 & Categories & $\mathrm{x}$ & $\mathrm{x}$ & $\mathrm{x}$ & $\mathrm{x}$ & $\mathrm{x}$ & $\mathrm{x}$ & - \\
\hline EORTC QLQ-BR23 & Categories & $\mathrm{x}$ & $\mathrm{x}$ & - & - & - & - & $\mathrm{x}$ \\
\hline FACT-B & Categories & $\mathrm{x}$ & $\mathrm{x}$ & - & $\mathrm{x}$ & - & $\mathrm{X}$ & $\mathrm{X}$ \\
\hline \multicolumn{9}{|l|}{ Group III } \\
\hline Lymph ICF & VAS & $\mathrm{x}$ & $\mathrm{x}$ & $\mathrm{x}$ & $\mathrm{x}$ & $\mathrm{x}$ & $\mathrm{x}$ & - \\
\hline ULL 27 & Categories & $\mathrm{x}$ & $\mathrm{x}$ & $\mathrm{X}$ & $\mathrm{x}$ & $\mathrm{x}$ & $\mathrm{x}$ & - \\
\hline LSIDS & Categories & $\mathrm{x}$ & $\mathrm{x}$ & $\mathrm{x}$ & $\mathrm{x}$ & $\mathrm{x}$ & $\mathrm{x}$ & $\mathrm{X}$ \\
\hline LyQLI & Categories & x & x & x & $\mathrm{x}$ & x & X & $\mathrm{X}$ \\
\hline PBI-L & Categories & $\mathrm{x}$ & $\mathrm{x}$ & $\mathrm{x}$ & $\mathrm{X}$ & $\mathrm{x}$ & $\mathrm{x}$ & - \\
\hline LYMQOL & Categories & $\mathrm{x}$ & $\mathrm{x}$ & $\mathrm{x}$ & $\mathrm{X}$ & $\mathrm{x}$ & $\mathrm{X}$ & - \\
\hline
\end{tabular}

VAS, visual analogue scale.

other four assessed all QoL, except for sexual function. One of the selected questionnaires was in Group I, one in Group II, and six were in Group III. Table 3 shows an overview of the assessed arm symptom-specific questions for each selected questionnaire.

The questionnaires from group I and II assessed only four out of nine arm symptoms. The questionnaires from group III assessed between six and nine arm symptoms. The LymphICF was the only questionnaire, which assessed all nine arm symptoms. The Lymphedema Quality of Life Inventory (LyQLI) assessed all arm symptoms, except for the possibility to wear the clothes of choice.

\section{Discussion}

A large number of questionnaires are currently used to assess QoL in BCRL patients. ${ }^{22-35}$ The objective of the present study was to provide an overview of the different questionnaires, to assess the most complete and accurate one to measure QoL.
Previous studies showed that lymphedema of the arm in breast cancer survivors did not influence global QoL. However, there was a major impact on many specific symptoms such as fatigue and arm symptoms. ${ }^{6-8}$ This suggests that more specific PROMs are needed to measure QoL. In this context, to measure the impact of lymphedema on QoL it is not only important to assess global QoL and the different QoL domains, but also to assess all specific arm symptoms.

The Lymph-ICF and the LyQLI assessed most QoL items, the different QoL domains, and the specific arm symptoms. In the Lymph-ICF all QoL domains, except for sexual function are assessed and all arm symptom-specific questions are assessed. In the LyQLI, all QoL domains are assessed and all arm-specific questions, except for the possibility of wearing all clothes of choice are assessed.

An important difference between the Lymph-ICF and the LyQLI is the answer type. The Lymph-ICF uses VAS, whereas the LyQLI uses categorical answers. A VAS is commonly used to rate various subjective experiences, and therefore it is often used in QoL measurements. Potential

Table 3. Overview of Arm Symptom-Specific Questions in Complete Questionnaires on Quality OF LIFE DOMAINS

\begin{tabular}{|c|c|c|c|c|c|c|c|c|c|}
\hline & Pain & Heaviness & $\begin{array}{l}\text { Swelling/ } \\
\text { tightness }\end{array}$ & $\begin{array}{c}\text { Loss } \\
\text { of strength }\end{array}$ & $\begin{array}{l}\text { Tingle/ } \\
\text { burning/pins }\end{array}$ & $\begin{array}{c}\text { Skin } \\
\text { problems }\end{array}$ & $\begin{array}{l}\text { Elevation } \\
\text { of the arm }\end{array}$ & $\begin{array}{l}\text { Movement } \\
\text { difficulties }\end{array}$ & $\begin{array}{c}\text { Wearing clothes } \\
\text { of choice }\end{array}$ \\
\hline \multicolumn{10}{|l|}{ Group I } \\
\hline DASH & $\mathrm{x}$ & - & - & $\mathrm{x}$ & $\mathrm{x}$ & - & - & $\mathrm{x}$ & - \\
\hline \multicolumn{10}{|l|}{ Group II } \\
\hline $\mathrm{C} 30+\mathrm{BR} 23$ & $\mathrm{x}$ & $\mathrm{x}$ & - & - & - & - & $\mathrm{x}$ & $\mathrm{x}$ & - \\
\hline \multicolumn{10}{|l|}{ Group III } \\
\hline Lymph-ICF & $\mathrm{x}$ & $\mathrm{x}$ & $\mathrm{x}$ & $\mathrm{x}$ & $\mathrm{x}$ & $\mathrm{x}$ & $\mathrm{x}$ & $\mathrm{x}$ & $\mathrm{x}$ \\
\hline ULL-27 & - & $\mathrm{x}$ & $\mathrm{X}$ & $\mathrm{x}$ & $\mathrm{x}$ & $\mathrm{X}$ & $\mathrm{x}$ & $\mathrm{x}$ & - \\
\hline LSIDS & $\mathrm{X}$ & $\mathrm{x}$ & $\mathrm{X}$ & 一 & $\mathrm{x}$ & 一 & $\mathrm{x}$ & $\mathrm{x}$ & - \\
\hline LyQLI & $\mathrm{x}$ & $\mathrm{x}$ & $\mathrm{x}$ & $\mathrm{x}$ & $\mathrm{x}$ & $\mathrm{x}$ & $\mathrm{x}$ & $\mathrm{x}$ & - \\
\hline PBI-L & $\mathrm{x}$ & - & $\mathrm{x}$ & 一 & 一 & $\mathrm{x}$ & - & $\mathrm{x}$ & $\mathrm{X}$ \\
\hline LYMQOL & $\mathrm{x}$ & $\mathrm{x}$ & $\mathrm{X}$ & $\mathrm{x}$ & $\mathrm{x}$ & 一 & - & $\mathrm{x}$ & $\mathrm{x}$ \\
\hline
\end{tabular}


advantages of these scales are the wide score range and high sensitivity. An important disadvantage is that they have a lower completion rate than other rating scales. ${ }^{38}$

In the present study the EORTC QLQ-C30 and QLQ-BR23 questionnaires were assessed together, because this combination is commonly used for breast cancer survivors. This questionnaire combination contains all QoL domains. However, only four out of nine arm symptom-specific questions were assessed in this combined questionnaire. Therefore, this questionnaire combination might not be accurate enough to measure QoL in patients with BCRL.

Another questionnaire which seemed to fulfill the demands after the first analysis was the DASH. The DASH also contains all QoL domains. However, similar to the QLQ-C30/ QLQ-B23, only four out of nine arm symptom-specific questions were assessed.

Both the DASH and the QLQ-C30/QLQ-BR23 did not contain questions about swelling of the arm. However, it should be mentioned that often before an increase in volume is measurable, patients experience symptoms such as tenderness and numbness of the arm. ${ }^{39}$

\section{Conclusion}

In conclusion, the Lymph-ICF and LyQLI questionnaires seem to be the two most complete and accurate questionnaires to assess QoL in patients. Based on our results, one of these two questionnaires should be used in research and clinical practice concerning QoL in BCRL patients.

\section{Acknowledgment}

The authors would like to thank professor C.H.C. Dejong for his help in the writing of the article and correcting the English. Ethics: There was no review of an institutional review board, because it is a review of the literature. No human subjects were involved.

\section{Author Disclosure Statement}

No competing financial interests exist.

\section{References}

1. Kiemeney LA, Lemmers FA, Verhoeven RH, Aben KK, Honing C, de Nooijer NJ, Peeters PH, Visser O, Vlems FA. The risk of cancer in the Netherlands. Ned Tijdschr Geneeskd 2008; 152:2233-2241.

2. Jemal A, Bray F, Center MM, Ferlay J, Ward E, Forman D. Global cancer statistics. CA Cancer J Clin 2011; 61:69-90.

3. Klein D, Mercier M, Abeilard E, Puyraveau M, Danzon A, Dalstein V, Pozet A, Guizard AV, Henry-Amar M, Velten M. Long-term quality of life after breast cancer: A French registry-based controlled study. Breast Cancer Res Treat 2011; 129:125-134.

4. Cano SJ, Klassen A, Pusic AL. The science behind qualityof-life measurement: A primer for plastic surgeons. Plast Reconstr Surg 2009; 123:98-106.

5. Sprangers MAG, Cull A, Groenvold M, Bjordal K, Blazeby J, Aaronsonand NK. The European Organization for research and treatment of cancer approach to developing Questionnaire Modules: An update and overview. Qual Life Res 1998; 7:291-300.
6. Arndt V, Stegmaier C, Ziegler H, Brenner H. A populationbased study of the impact of specific symptoms on quality of life in women with breast cancer 1 year after diagnosis. Cancer 2006; 107:2496-2503.

7. Dawes D.J, Meterissian S, Goldberg M, Mayo NE. Impact of lymphoedema on arm function and health-related quality of life in women following breast cancer surgery. J Rehabil Med 2008; 40:651-658.

8. Beaulac SM, Mcnair LA, Scott TE, LaMorte WW, Kavanah MT. Lymphedema and quality of life in survivors of early-stage breast cancer. Arch Surg 2002; 137:1253-1257.

9. Passik SD, McDonald MV. Psychosocial aspects of upper extremity lymphedema in women treated for breast carcinoma. Cancer 1998; 83:2817-2820.

10. Passik S, Newman M, Brennan M, Holland J. Psychiatric consultation for women undergoing rehabilitation for upper-extremity lymphedema following breast cancer treatment. J Pain Symptom Manage 1993; 8:226-233.

11. Tobin MB, Lacey HJ, Meyer L, Mortimer PS. The psychological morbidity of breast cancer-related arm swelling: Psychological morbidity of lymphoedema. Cancer 1993; 72:3248-3252.

12. McWayne J, Heiney SP. Psychologic and social sequelae of secondary lymphedema. Cancer 2005; 104:457-466.

13. Kuehn T, Klauss W, Darsow M, Regele S, Flock F, Maiterth C, Dahlbender R, Wendt I, Kreienberg R. Long-term morbidity following axillary dissection in breast cancer patients: Clinical assessment, significance for life quality and the impact of demographic, oncologic and therapeutic factors. Breast Cancer Res Treat 2000; 64:275-286.

14. Wilke LG, McCall LM, Posther KE, Whitworth PW, Reintgen DS, Leitch AM, Gabram SG, Lucci A, Cox CE, Hunt KK, Hendon JE II, Giuliano AE. Surgical complications associated with sentinel lymph node biopsy: Results from a prospective international cooperative group trial. Ann Surg Oncol 2006; 12:491-500.

15. Fisher B, Redmond C, Fisher ER, Bauer M, Wolmark N, Wickerham DL, Deutsch M, Montague E, Margolese R, Foster R. Ten-year results of a randomized clinical trial comparing radical mastectomy and total mastectomy with or without radiation. N Engl J Med 1985; 312:674-681.

16. Penha TR, Botter B, Heuts EM, Voogd AC, von Meyenfeldt MF, van der Hulst RR. Quality of life in patients with Breast Cancer Related Lymphedema and reconstructive breast surgery. J Reconst Microsurg 2016; 32:484-490.

17. Ganz PA. The quality of life after breast cancer-solving the problem of lymphedema. N Engl J Med 1999; 340:383385 .

18. Di Sipio T, Rye S, Newman B, Hayes S. Incidence of unilateral arm lymphoedema after breast cancer: A systematic review and meta-analysis. Lancet Oncol 2013; 14:500-515.

19. Lopez Penha TR, van Bodegraven J, Winkens B, Heuts EM, Voogd AC, von Meyenfeldt MF. The quality of life in long-term breast cancer survivors with breast cancer related lymphedema. Acta Chir Belg 2014; 114:239-244.

20. Rockson SG. Lymphedema. Am J Med 2001; 110:288-295.

21. Ahmed RL, Prizment A, Lazovich D, Smitz KH, Folsom AR. Lymphedema and quality of life in breast cancer survivors: The Iowa Women's Health Study. J Clin Oncol 2008; 26:5689-5696.

22. Dias JJ, Rajan RA, Thompson JR. Which questionnaire is best? The reliability, validity and ease of use of the patient evaluation measure, the disabilities of the arm, shoulder 
and hand and the Michigan Hand outcome measure. J Hand Surg Eur 2008; 33:9-17.

23. Barbosa Lima PM, Fernanded de Brito R, Fernandes de Brito Farias RT, Souza de Paiva G, Barbosa FT, Fernando de Sousa Rodirues C, Calheiros da Silva PN. Cultural adaption and reproducibility of the Measure Yourself Medical Outcome Profile (MYMOP 2). Fisioter Mov 2016; 29:251-267.

24. Devoogdt N, van Kampen M, Geraerts I, Coremans T, Christiaans MR. Lymphoedema functioning, disability and health questionnaire (Lymph-ICF): Reliability and validity. Phys Ther 2011; 91:944-957.

25. Launois R, Mègnigbeto AC, Pocquet K, Alliot F. A specific quality of life scale in upper limb lymphedema: The ULL27 questionnaire. Lymphology 2002; 35:1-760:181-187.

26. Bjelland I, Dahl AA, Haug TT, Neckelmann D. The validity of the Hospital Anxiety and Depression Scale. An updated literature review. J Psychosom Res 2002; 52:69-77.

27. Melzack R. The short-form McGill Pain Questionnaire. Pain 1987; 30:191-197.

28. Ridner SH, Dietrich MS. Development and validation of the Lymphedema symptom and intensity survey-arm. Support Care Cancer 2015; 23:3103-3112.

29. Klernäs P, Johnsson A, Horstmann V, Kristjanson LJ, Johansson K. Lymphedema Quality of Life Inventory (LyQLI)development and investigation of validity and reliability. Qual Life Res 2015; 24:427-439.

30. Watson D, Clark LA, Tellegen A. Development and validation of brief measures of positive and negative affect: The PANAS scales. J Pers Soc Psychol 1988; 54:10631070.

31. Brazier JE, Harper R, Jones NM, O'Cathain A, Thomas KJ, Usherwood T, Westlake L. Validating the SF-36 health survey questionnaire: New outcome measure for primary care. BMJ 1992; 305:160-164.

32. Sprangers MA, Groenvold M, Arraras JI, Franklin J, te Velde A, Muller M, Franzini L, Williams A, de Haes HC, Hopwood P, Cull A, Aaronson NK. The European Organization for Research and Treatment of Cancer breast cancer-specific quality-of-life questionnaire module: First results from a three-country field study. J Clin Oncol 1996; $14: 2756-2768$.

33. Tan ML, Idris DB, Teo LW, Loh SY, Seow GC, Chia YY, Tin AS. Validation of EORTC QLQ-C30 and QLQ-BR23 questionnaires in the measurement of quality of life breast cancer patients in Singapore. Asia Pac J Oncol Nurs 2014; $1: 22-32$.

34. Coster S, Poole K, Fallowfield LJ. The validation of a quality of life scale to assess the impact of arm morbidity in breast cancer patients post-operatively. Breast Cancer Res Treat 2001; 68:273-282.

35. Blome C, Augustin M, Heyer K, Knöfel J, Cornelsen H, Purwins S, Herberger K. Evaluation of patient-relevant outcomes of lymphedema and lipedema treatment: Development and validation of a new benefit tool. Eur J Vasc Endovasc Surg 2014; 47:100-107.

36. Keeley V, Crooks S, Locke J, Veigas D, Riches K, Hilliam R. A quality of life measure for limb lymphedema (LYMQOL). J Lymphoedema 2010;5:26-37.

37. Moher D, Liberati A, Tetzlaff J, Altman DG, et al. Preferred reporting items for systematic reviews and metaanalyses: The PRISMA statement. Ann Intern Med 2009; 151:264-269.

38. Hauser K, Walsh D. Visual analogue scales and assessment of quality of life in cancer. J Support Oncol 2008; 6:277-282.

39. Armer J, Fu MR, Wainstock JM, Zagar E, Jacobs LK. Lymphedema following breast cancer treatment, including sentinel lymph node biopsy. Lymphology 2004; 37:73-91.

Address correspondence to:

Shan Shan Qiu, MD, PhD

Department of Plastic and Reconstructive Surgery Maasticht University Medical Center P. Debyelaan 25

Maastricht 6229 HX

The Netherlands

E-mail: shanshan.qiushao@mumc.nl 